\title{
Study on Microbial Quality of Different Water Sources Intended for Livestock Feeding in Thiruvallur District of Tamil Nadu, India
}

\author{
J.A. Jimy Carolin ${ }^{1 *}$, A. Yasotha ${ }^{1}$, T. Sivakumar ${ }^{1}$, K. Porteen ${ }^{2}$ and S.J. Deepak ${ }^{2}$
}

${ }^{1}$ Department of Livestock Production Management, ${ }^{2}$ Department of Veterinary Public Health and Epidemiology, Madras Veterinary College, TANUVAS, Chennai-7, Tamil Nadu, India

*Corresponding author: indiajimyvet @ gmail.com

\section{A B S T R A C T}

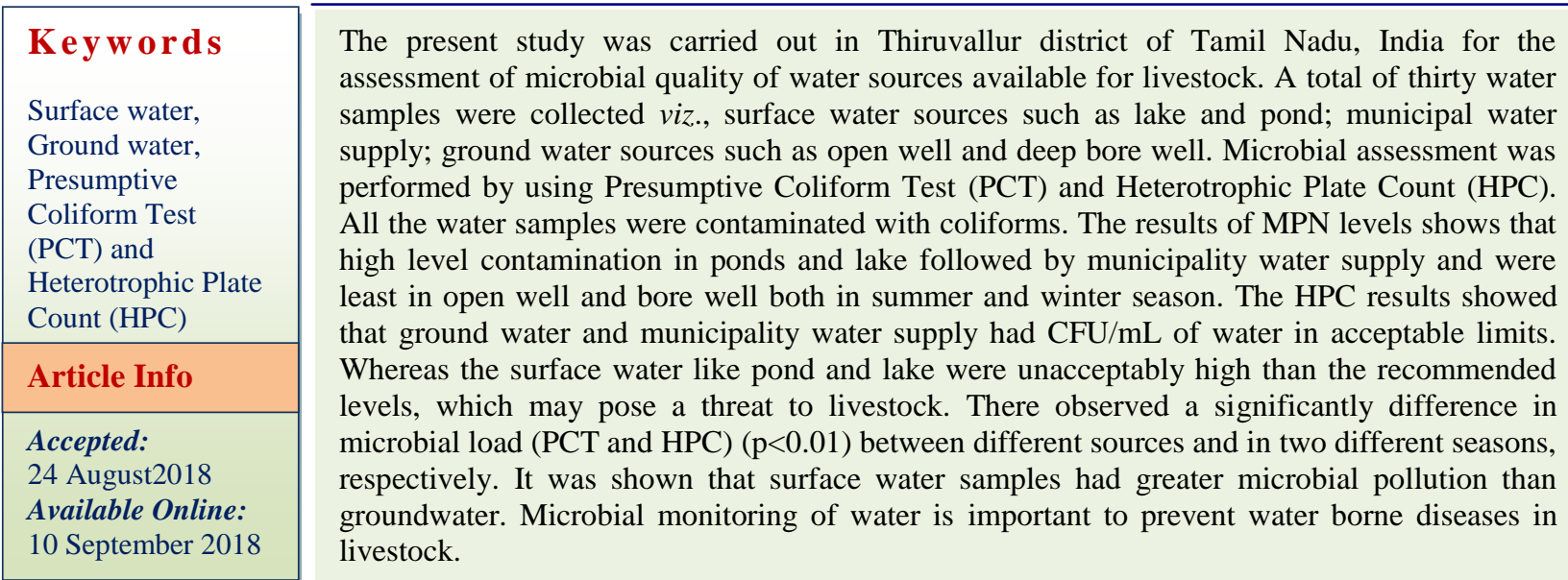

\section{Introduction}

Water is a vital nutrient needed for sustaining life and to optimize the milk production, growth rate and reproduction in livestock (Beede, 2006) but unfortunately it is a poorly studied component (Schlink et al., 2010). The water supply for livestock could come from a number of sources with different water quality. The resources of water were classified into surface water and ground water. Surface water sources were ponds or pools, lakes, river and stream and ground water was classified as open wells, water holes and bore well which originate from infiltration of rainfall (Pagot, 1992). A variety of microbial pathogens such as bacteria, viruses, protozoa and parasites could be transmitted to livestock from drinking water sources. The risk of contamination was found to be greatest in surface waters that were directly accessible by livestock or contaminated due to runoff or drainage from a manure source but ground water had low level of bacterial contamination (Davis, 2016). 
Water sources are generally contaminated by various types of microorganisms. Both ground water and surface water may get microbiologically contaminated by a variety of means including agricultural runoff, improper sanitation, accumulation of minerals due to runoff, etc. (Geldreich, 1990; Grabow et al., 1996; WHO, 2008). The presence of organic substances major reason for odours in water and some odours were indicative of increased biological activity and from industrial pollution. The presence of coliforms could indicate faecal contamination of water which account for severe water borne fatal diseases and therefore rapid detection of coliforms in drinking water was necessary which could be carried out by MPN (Most Probable Number) to determine the portability or safety of water (Goel et al., 2007; Aberaet al., 2011). In dairy cows more than $95 \%$ of udder infections are caused by agents spread by alimentary way (Streptococcus agalactiae, Staphylococcus aureus, Mycoplasma spp.) or by environmental agents such as Streptococcus dysgalactiae, Streptococcus uberis, Escherichia coli (Tancin, 2008). Coliforms in drinking can lead to diarrhoea, urinary tract infections, mastitis and many other deadly infections and thereby can also affect the production performance. It is important to study the microbial monitoring or an assessment of water periodically for improving the health status of animals.

\section{Materials and Methods}

\section{Sample collection}

Water samples were collected in different seasons i.e., summer and winter (November 2017 to May 2018). The samples were collected from surface water sources such as lake and pond; municipal water supply and ground water sources such as open well and deep bore well that were intended for feeding livestock in Thiruvallur district of Tamil
Nadu, India. Water sampling was done at various points of the water sources in sterile $500 \mathrm{~mL}$ containers and transported to laboratory under refrigeration conditions and stored at $4^{\circ} \mathrm{C}$ till analysis.

\section{Microbial assessment}

The water samples were subjected to Presumptive Coliform test and Standard Plate Count/Heterotrophic Plate Count (HPC) for quality assessment. Presumptive Coliform test was performed by Most Probable Number (MPN) technique (Rompre et al., 2002) and Standard Plate Count (SPC)/ Heterotrophic Plate Count (HPC) using Pour plate method (Varga, 2011).

\section{Presumptive coliform test}

The test was primarily intended for detection of the Gram negative coliform bacteria in the water samples (Cappuccino and Sherman, 1996). It was performed by multiple tube fermentation method/ Most Probable Number Method. The three tube procedure using lactose broth (Bakare et al., 2003) and various strengths of broth and sample. Single strength lactose broth and double strength lactose broth was added with Alizarin dye to appreciate the colour change due to acid production (Amagloh and Benang, 2009). Multiple tube fermentation method was adopted. Three tube method was followed in which three sets of three test tubes in each set were taken. The double strength lactose broth was dispensed in first set of three tubes and was added with equal amount of water sample (1:1 dilution). In second set, $1 \mathrm{~mL}$ of water sample and 9 $\mathrm{mL}$ single strength lactose broth was taken (1:10 dilution). In third set, $0.1 \mathrm{~mL}$ of water sample and $9.9 \mathrm{~mL}$ single strength lactose broth (1:100 dilution). Durham tubes were added in inverted position in all the sets of test tubes. The test tubes been inoculated were incubated at $37^{\circ} \mathrm{C}$ for 24 hours and the results 
were observed. The number of coliforms present in the sample was estimated by number of tubes showing positive results and comparing it with Most Probable Number chart or McCrady's table. The number of coliforms/100 mL was recorded (WHO, 1996; Smith et al., 2013). The positive samples were confirmed by streaking it on Eosin Methylene Blue Agar as a confirmatory test.

\section{Standard plate count or heterotrophic plate count}

Standard Plate Count (SPC) or Heterotrophic plate count (HPC) is a culture based method that could measure bacterial colonies in drinking water. It was performed by Pour plate method (WHO, 2002).An aliquot of nine $\mathrm{ml}$ sterile PBS was taken in serial test tubes. For the first tube, one $\mathrm{ml}$ of water sample was added and mixed properly. From the first tube a serial dilution of $1 \mathrm{~mL}$ was made to subsequent test tubes and so on(1:10 dilution). One $\mathrm{mL}$ of sample was taken from serially diluted water sample and poured into the sterile petri dish. The molten plate count agar (approx. $45-50^{\circ} \mathrm{C}$ ) was poured over the sample and mixed gently by rotating the plates and allowed to solidify. After the agar was set, the plates were inverted and incubated at $37^{\circ} \mathrm{C}$ overnight. The incubated plates were counted using colony counter manually. The total number of bacteria or the number of colony forming units (CFU) present in the sample was estimated by multiplying dilution factor (Smith et al., 2013).

\section{Results and Discussion}

\section{Presumptive coliform test}

The water samples from various water sources were positive for coliforms. The results are showed in Table 1 indicated that all pose risk of coliform contamination. The results of MPN levels shows that high level contamination in ponds and lake followed by municipality water supply and were least in open well and bore well both in summer and winter season. There observed a significantly difference in microbial load $(\mathrm{p}<0.01)$ between sources in two different seasons, respectively. The surface waters such as pond and lake had higher coliforms than groundwater sources. Similar results were obtained by Zodape et al., (2013) in their study on quality assessment of drinking water in Mumbai, India. According to NRC water quality guidelines for cattle (2001) the permissible level of coliforms was 50-100/ mL. The present results showed that ground water and municipality water supply had coliform count in acceptable limits but surface water like pond and lake were unacceptably high, which may pose a threat to livestock. Similarly, Olkowski (2009) recommended that drinking water for livestock should contain less than 100 coliforms $/ 100 \mathrm{~mL}$. The sunlight was among the most potent abiotic factors in the inactivation or killing of indicator bacteria like E. coli in environmental waters and it reduced E. coli densities in water (Whitman et al., 2004) but our finding was antagonist may be due to varied reasons such as continued contamination and duration of sunlight suboptimum.

\section{Heterotrophic plate count}

The presence of viable bacterial count of water is enumerated with as Standard Plate Count. The same in water sample is known as Heterotrophic plate count. The results were depicted in Table 2 for various water sources. There observed a significantly difference in microbial load $(\mathrm{p}<0.01)$ between different sources and in two different seasons, respectively. The present results showed that ground water and municipality water supply had CFU/mL of water in acceptable limits. Whereas the surface water like pond and lake were unacceptably high than the 
recommended levels, which may pose a threat to livestock. The results indicate that total bacterial count was higher in surface water sources like pond and lakes than municipality water supply and ground water. Similar results were obtained by (Toroglu and Toroglu, 2009) in their study on microbial pollution of water in Golbasi Lake in Adiyaman, Turkey. The results of bacterial count were higher than permissible levels recommended by NRC, 2001. NRC had recommended a count of $1000 / \mathrm{mL}$ of water for livestock whereas Van et al.(2013) suggested that drinking water containing bacterial count of $<100,000 \mathrm{CFU}$ $/ \mathrm{mL}$ could be used for livestock.

Table.1 Comparison of mean MPN index per $100 \mathrm{ml}$ in presumptive coliform test for different sources and season

\begin{tabular}{|c|c|c|c|c|}
\hline Sources & $\begin{array}{c}\text { Mean } \pm \text { SE } \\
\text { Winter }\end{array}$ & F value & $\begin{array}{c}\text { Mean } \pm \text { SE } \\
\text { Summer }\end{array}$ & F value \\
\hline Lake & $886.66 \pm 134.92$ & \multirow{2}{*}{$40.83^{* *}$} & $288.33 \pm 57.17$ & $8.28^{* *}$ \\
\hline Pond & $993.33 \pm 106.66$ & & $441.66 \pm 141.47$ & \\
\hline Municipal water & $57.83 \pm 11.12$ & & $36.33 \pm 6.58$ & \\
\hline Open well & $41.66 \pm 7.44$ & & $16.16 \pm 4.30$ & \\
\hline Bore well & $29.50 \pm 5.65$ & & $8.50^{\mathrm{aB}} \pm 2.33$ & \\
\hline
\end{tabular}

Note: ** level of significance $(\mathrm{p}<0.01)$

Table.2 Comparison of mean CFU/mL of Total bacterial count/SPC in different sources and season

\begin{tabular}{|c|c|c|c|c|}
\hline Sources & $\begin{array}{c}\text { Mean } \pm \text { SE } \\
(\log \text { CFU/ml) } \\
\text { Winter }\end{array}$ & F value & $\begin{array}{c}\text { Mean } \pm \text { SE } \quad(\log \\
\text { CFU/ml) } \\
\text { Summer }\end{array}$ & F value \\
\hline Lake & $6.23 \pm 0.26$ & \multirow{5}{*}{$41.58^{* *}$} & $4.81 \pm 0.22$ & \multirow{5}{*}{$10.32 * *$} \\
\hline Pond & $6.49 \pm 0.18$ & & $5.22 \pm 0.60$ & \\
\hline Municipal water & $4.29 \pm 0.06$ & & $4.24 \pm 0.05$ & \\
\hline Open well & $4.40 \pm 0.06$ & & $4.31 \pm 0.08$ & \\
\hline Bore well & $3.98 \pm 0.24$ & & $3.95 \pm 0.24$ & \\
\hline
\end{tabular}

Note: $* *$ level of significance $(\mathrm{p}<0.01)$ 


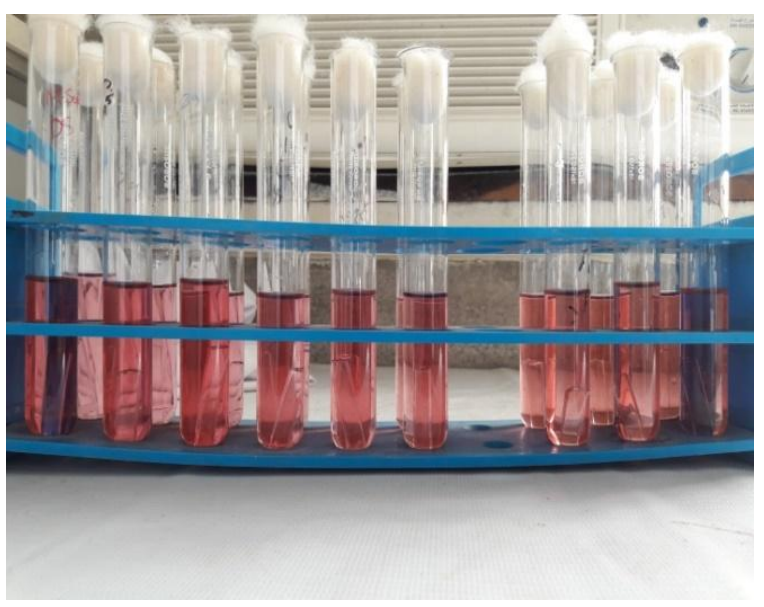

Plate.1 Water samples containing Lactose broth with durham tubes before incubation

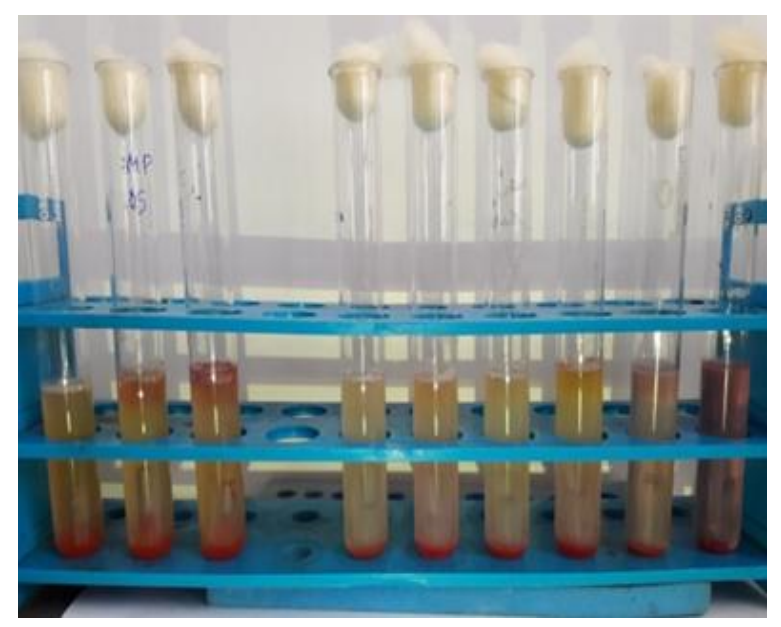

Plate. 2 Acid and gas production after 24 hours of incubation at $37^{\circ} \mathrm{C}$

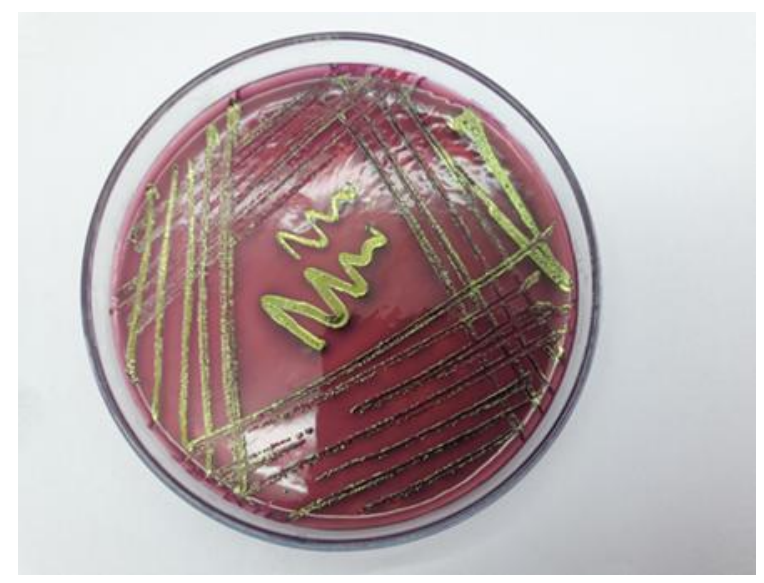

Plate.3 E. coli on EMB Agar

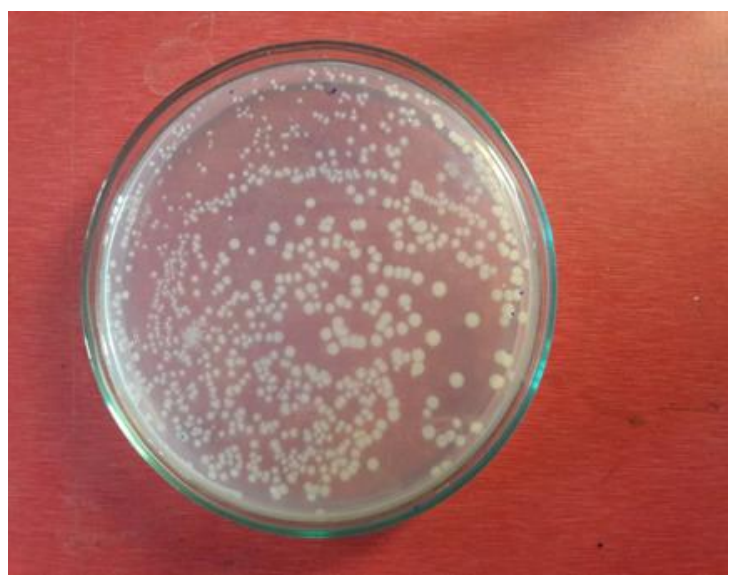

Plate.4 Heterotrophic plate count

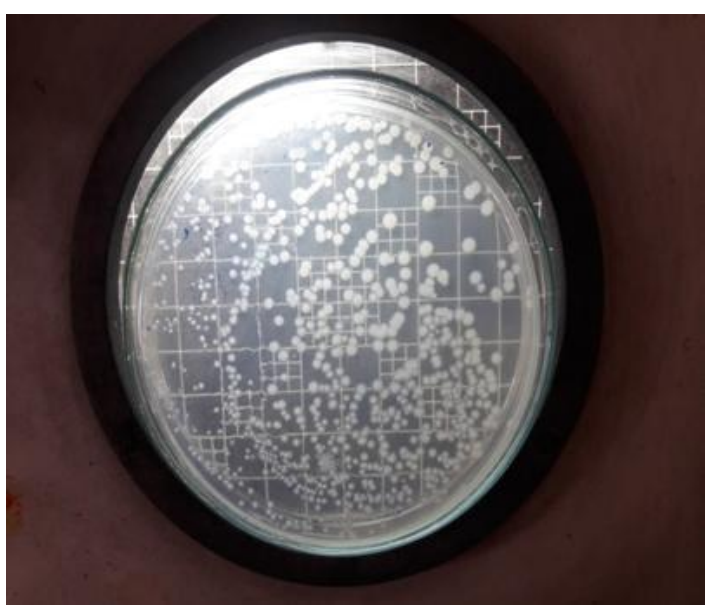

Plate.5 Bacterial colonies on colony counter 
In conclusion, the quality of drinking water for livestock is not given significant consideration and mainly reared on low quality water sources throughout the world. The microbial load showed that ground water and municipality water supply had MPN and $\mathrm{CFU} / \mathrm{mL}$ of water in acceptable limits. Whereas the surface water like pond and lake were unacceptably high than the recommended levels, which may pose a threat to livestock. All the water samples were contaminated with coliforms suggestive of sewage seepage to groundwater. Monitoring of water quality is important as poor quality water can cause low production and impairment of health. Water quality can influence the production in an indirect way, hence periodic monitoring of water and necessary action has to carry out to minimise the loss of production and health.

\section{References}

Abera, S., A. Zeyinudin, B. Kebede, A. Deriew, S. Ali and E. Zemene. 2011. Bacteriological analysis of drinking water sources. Afr. J. Microbiol. Res. 5 (18): 2638-2641.

Amagloh, F.K. and A.Benang, 2009. Effectiveness of Moringa oleifera seed as coagulant for water purification. Afr. J. Agric. Res., 4(1): 119-123.

APHA, 1992.Standard methods of examination of water and waste water. American Public Health Association (Washington).

Bakare, A.A., A. Lateef, O.S. Amuda and R.O. Afolabi. 2003. The Aquatic toxicity and characterization of chemical and microbiological constituents of water samples from Oba River, Odo-oba, Nigeria. Asian J. Microbiol. Biotechnol. Environ. Sci.5: 11-17.

Beede, D.K., 2006. Evaluation of water quality and nutrition for dairy cattle. High Plains Dairy Conference, Michigan State University. pp. 129154.

Cappuccino, J.G. and Sherman, N. 1996.Microbiology- A Laboratory Manual. The Benjamin/ Cummings publishing Co., Inc., Menlo Park, California.

Davis, R. Water quality. Feed lot design and construction. 2016. pp.1-13.

Geldreich, E.E. 1990. Microbiological quality of source waters for water supply. pp. 3-31

Goel, S., R.Sood, S.R. Mazta, P.Bansal and A.Gupta. 2007. Bacteriological quality of water samples of a tertiary care medical center campus in Northwestern Himalayan region of India. Inter. J. Third World Med. 5 (1): 1-11.

Grabow, W.O.K. 1996. Water borne Diseases: Update on water quality assessment and control. Water SA. 22: 193-202.

NRC, 2001. Nutrient Requirements of Dairy Cattle 7th revised edition. National Research Council, National Academy of Sciences, Washington, DC, USA.

Pagot, Jean.1992. Animal production in the tropics. The Macmillan Press Limited, London

Rompre, A., P. Servais, J. Baudart, M.R.deRoubin and P. Laurent. 2002. Detection and enumeration of coliforms in drinking water: current methods and emerging approaches. Journal of microbiological methods, 49 (1): 31-54.

Schlink A.C., M.L. Nguyen and G.J. Viljoen. 2010. Water requirements for livestock production a global perspective. Rev Sci Tech. 603-19.

Smith, J.J., A. Keegan, G. McGregor, M. Smith, A. Hieatt, A. McNeill and B. Gray. 2013. Water microbiology.112: 
19054-19056.

Tancin, V. 2008. Management in dairy industry, Science Institute of Animal Production, pp. 50.

Toroglu, E. and S.Toroglu. 2009. Microbial pollution of water in Golbasilake in Adiyaman, Turkey. J. Environ. Biol. 30(1): 33-38.

Whitman, R.L., M.B. Nevers,G.C.Korinek and M.N. Byappanahalli.Solar and temporal effects on Escherichia coli concentration at a Lake Michigan Swimming Beach. 2004. Appl. Environ. Microbiol., 70 (7): 42764285.

WHO (World Health Organization). 2003. Assessing microbial safety of drinking water- improving approaches and methods. WHO \& OECD, IWA publishing, London, UK.
WHO, 1996. Water Quality Monitoring - A Practical Guide to the Design and Implementation of Freshwater Quality Studies and Monitoring ProgrammesMicrobial analyses.

WHO, 2002.Guidelines for drinking water quality. Microbiological agents in drinking water.

Varga, L. 2011. Bacteriological quality of bottled natural mineral waters commercialized in Hungary. Food Control. 22(3-4), 591-595.

Zodape, G.V., V.L. Dhawan, R.R, Wagh, V.N. Magare. 2013. Analysis of heavy metals and coliforms in drinking water collected from municipal ward offices of western suburbs and extended western suburbs of Mumbai, India. Bionano Front. 6(2): 252-259.

\section{How to cite this article:}

Jimy Carolin, J.A., A. Yasotha, T. Sivakumar, K. Porteen and Deepak, S.J. 2018. Study on Microbial Quality of Different Water Sources Intended for Livestock Feeding in Thiruvallur District of Tamil Nadu, India. Int.J.Curr.Microbiol.App.Sci. 7(09): 3603-3609.

doi: https://doi.org/10.20546/ijcmas.2018.709.446 